\title{
Foreign Acquisitions by Indian Multinational Enterprises: Testing and Extending Internationalisation Frameworks
}

\author{
Surender Munjal \\ Ph.D. awarded by University of Leeds, UK, September 2013
}

ThIS THESIS TESTS THE APPLICABILITY OF THE OLI (Ownership-Location-Internalisation), and the LLL (Linkage-Leverage-Learning) frameworks in the case of Indian multinational enterprises' (MNEs) internationalisation through foreign acquisitions. It contributes to the academic debate about the need for new theories that explain the internationalisation of MNEs from emerging economies (EMNEs) by ascertaining which aspects of the theoretical explanations are valid, and which are not (Cuervo-Cazurra, 2012; Mathews, 2006; Ramamurti, 2012). In this process, it answers some intriguing questions presented in the literature, such as do EMNEs possess ownership advantages? And, if so, what are the sources of their ownership advantages?

It also reconciles the extreme views of internationalisation, i.e., asset exploitation view, and asset augmentation view, embedded within the Ownership-Location-Internalisation and the Linkage-Leverage-Learning frameworks, respectively, by exploring complementarities between the frameworks. In practice, MNEs are not ruled by frameworks. MNEs exploit their ownership advantages, and also form linkages (networks) to augment strategic assets. Thus, asset exploitation and augmentation strategies occur simultaneously, and the real research challenge is to explore how MNEs dovetail these strategies. To discover which aspects of the frameworks complement, and which compete, various interactions between tenets of both frameworks, at both country and firm level, were formulated.

Results suggest that the frameworks are complementary, and that they explain different facets of internationalisation (Dunning, 2006; Mathews, 2006; Narula, 2006). Indian MNEs possess ownership advantages, which are exploited by combining them with resources acquired from foreign networks. However, foreign networks may not always be favourable, particularly where resources obtained from foreign networks are incompatible with existing assets. The findings are presented in four papers, which are summarised below. Table 1 shows the research design and the structure of the thesis.

\section{Paper 1}

Home country effects are found to be significant in determining crossborder acquisitions undertaken by Indian MNEs. Specifically, home institutions and market structures contribute to country specific advantages. Higher stock valuations in the Indian capital market lower the cost of capital and provide funds for acquisitions. This effect is further strengthened by the appreciation of the Indian Rupee against the US dollar, and the liberalisation of outward FDI policy which removed the absolute cap on outward investment and enabled Indian companies to undertake more and larger foreign acquisitions.

In addition to the above economic factors, proficiency in the English language assisted Indian MNEs to invest in English speaking countries, particularly the UK and the USA, where they have sought market and strategic assets, such as brands and technology. Further, the experience of operating in a risky political environment at home has made Indian MNEs resilient towards political risk. This is a country specific advantage which has empowered Indian MNEs to invest in developing economies of Asia, Africa and South America to seek natural resources.

The paper also tests the impact of country specific linkages on the internationalisation of Indian MNEs. Different types of associations, such as economic-political alliances and trade linkages between nations were used to measure country specific linkages. North-South types of country alliances, such as the Commonwealth, and trade linkages provided additional explanatory power (Buckley, Enderwick, Forsans and Munjal, 2013).

\section{Paper 2}

Indian MNEs' foreign trade and investment linkages were also found significant. This has not only given them exposure and experience of foreign markets but has also helped them identify foreign acquisition

Table 1: Research Design

\begin{tabular}{|c|c|c|c|}
\hline \multicolumn{4}{|c|}{ Internationalisation Frameworks } \\
\hline \multirow{3}{*}{ 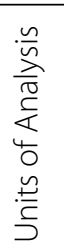 } & $\mathrm{OLI}$ & $\mathrm{LLL}$ & Complementarity between \\
\hline & $\begin{array}{l}\text { Country } \\
\text { Level }\end{array}$ & $\begin{array}{l}\text { Country-Level Determinants } \\
\text { Paper } 1\end{array}$ & $\begin{array}{l}\text { Country Specific Advantages and Country Specific Linkages } \\
\text { Paper } \mathbf{3}\end{array}$ \\
\hline & $\begin{array}{l}\text { Firm } \\
\text { Level }\end{array}$ & $\begin{array}{l}\text { Firm-Level Determinants } \\
\text { Paper } 2\end{array}$ & $\begin{array}{c}\text { Firm Specific Advantages and Foreign Network Resources } \\
\text { Paper } \mathbf{4}\end{array}$ \\
\hline
\end{tabular}


opportunities. Furthermore, resources acquired through foreign linkages have helped Indian MNEs build competitive advantages for internationalisation and overcome resource deficiencies. More specifically, Indian MNEs in technologically intensive industries, such as automobiles, pharmaceuticals, renewable energy, software and telecommunications, have augmented foreign knowledge-based resources to enhance their competitive advantages.

The asset exploitation hypothesis was examined to explore what kinds of firm specific advantages are possessed by Indian MNEs. Findings suggest that Indian MNEs possess financial reserves, which are exploited in making foreign acquisitions. It is argued that these financial resources are an outcome of imperfections in the home market. The late liberalisation of the home economy provided Indian MNEs monopolistic access to a large sheltered market for a long time. As a result, many Indian MNEs grew strongly accumulating financial reserves that can be used to undertake acquisitions to obtain resources not available at home.

This confirms previous studies that EMNEs may lack other traditional competitive advantages, such as managerial or marketing skills. Even though Indian MNEs serve a large diverse market at home, their managerial and marketing skills are not sufficient to enable them to be internationally competitive. However, Indian MNEs possess adequate technological ownership advantages in some industries that facilitate the absorption of foreign technological resources.

\section{Paper 3}

This paper explores complementarities amongst country-level determinants by testing interactions between home-host country distance and country specific linkages. It finds that home country linkages influence Indian MNEs' location choice and internationalisation strategy by moderating the negative effect of different kinds of distances, such as economic, cultural and geographic, between home and host countries. For example, an economic-political alliance, such as the British Commonwealth, bridges the cultural and economic distance amongst member countries through cultural and sporting events, policy similarities, and strengthening democracy and transparency. All these measures facilitate internationalisation of the MNE by reducing transaction costs associated with home-host distance (Buckley, Forsans, \& Munjal, 2012).

Furthermore, results show that linkages between home and host countries complement country specific ownership advantages by adding to the overall explanatory power of country specific advantages in explaining foreign acquisitions undertaken by Indian MNEs.

\section{Paper 4}

Interactions between foreign network resources and firm specific advantages are used to explore complementarities amongst firm-level determinants. It is found that network resources leveraged by Indian MNEs through foreign linkages can both assist, and impede, their internationalisation. Foreign technological resources assist by supplementing the technological resources of Indian MNEs, and complementing their financial resources. Own technological resources contribute to absorptive capacity and allow the MNE to benefit from foreign technological know-how. Own financial resources provide funds for investment to exploit assimilated foreign technology. In contrast, foreign financial resources impede Indian MNEs'internationalisation. This occurs because finance is a substitutable resource. A financially affluent MNE can exchange its local currency financial reserves for foreign currency, making foreign finance redundant. Furthermore, foreign investors may prefer Indian MNEs to concentrate on growth in the domestic market rather than risking investment abroad. Thus, foreign financial resources make an imprudent combination with the Indian MNEs' own resources.

At the framework level, the results show that Indian MNEs'linkage, leverage and learning from foreign sources complement their firm specific advantages, and add to the overall explanatory power of firm specific advantages in illuminating the internationalisation of Indian MNEs.

\section{Implications}

The main contribution of the thesis lies in explaining the mechanisms through which the Ownership-Location-Internalisation and the Linkage-Leverage-Learning frameworks can be complementary, both at the country and firm level. It confirms that home country effects are strong in explaining EMNEs' internationalisation. They shape EMNEs' capabilities and resources, and also influence their location choice. It also extends the LLL framework by exploring the positive effects of country specific linkages. It suggests to policy makers in emerging economies that some protection at home and linkages with other countries can facilitate the internationalisation of their local firms.

At the firm level, managers should look beyond the boundary of the firm and exploit home country linkages. They should consider the effects of foreign resources and understand that not all of them will facilitate the firm's internationalisation. Some may create an impediment. Theoretically, this research extends the Linkage-Leverage-Learning framework and the current perspective of the resource-based view, which presents a rather myopic view of the role of network resources which fails to distinguish between supporting and impeding effects.

\section{References}

Buckley, P. J., Forsans, N., \& Munjal, S. 2012. Host-home country linkages and host-home country specific advantages as determinants of foreign acquisitions by Indian firms. International Business Review, 21(5): 878-890. 
Buckley, P. J., Enderwick, P., Forsans, N. \& Munjal, S. 2013. Country linkages and firm internationalisation: Indian MNEs within economicpolitical alliances of nations. In Cook, G. \& Johns, J. (Eds.) The Changing Geography of International Business. Basingstoke, Palgrave MacMillan.

Cuervo-Cazurra, A. 2012. Extending theory by analyzing developing country multinational companies: Solving the goldilocks debate. Global Strategy Journal, 2(3): 153-167.

Dunning, J. H. 2006. Comment on Dragon multinationals: New players in 21st century globalization. Asia Pacific Journal of Management, 23(2): 139-141.

Mathews, J. A. 2006. Response to Professors Dunning and Narula. Asia Pacific Journal of Management, 23(1): 153-155.

Narula, R. 2006. Globalization, new ecologies, new zoologies, and the purported death of the eclectic paradigm. Asia Pacific Journal of Management, 23(2): 143-151.

Ramamurti, R. 2012. What is really different about emerging market multinationals? Global Strategy Journal, 2(1): 41-47.

Surender Munjal is a Lecturer in International Business, and the Director of the India and South-Asia Business Centre, Leeds University Business School. His research focuses on internationalisation strategies of multinational enterprises from emerging economies. His PhD thesis was also a finalist for the ITC Dissertation Awards at the AOM 2014 conference. He has earned M.Phil in Marketing from the Delhi School of Economics. He is also a Chartered Accountant, and Cost and Management Accountant. 